Лісневський Р. В., канд. техн. наук, доцент

(0000-0002-9006-6366)

Костіков М. П., канд. техн. наук, доцент

$(0000-0002-1569-8179)$

Гладка М. В

(0000-0001-5233-2021)

Київський національний університет імені Тараса Шевченка, Київ

\title{
Аналіз інтеграцій програмних інструментаріїв ведення просктів щодо можливості їх використання для потреб Збройних Сил України
}

Резюме. Стаття присвячена аналізу проблем оцінювання придатності інструментаріїв ведення проєктів різних масштабів під час створення інформаційних систем військового призначення. Приведені приклади вже впроваджених проєктів за допомогою різноманітних інструментаріїв, виявлені і описані переваги та недоліки основних програмних інструментаріїв для ведення проєктів. Обгрунтовано доцільність використання інструментарію MS Project для створення інформаційних систем військового призначення.

Ключові слова: управління проєктом; інструментарії ведення проєктів; управління ресурсами.

Постановка проблеми. Забезпечити ефективне управління проєктами у різних сферах діяльності Збройних Сил (3С) України без використання сучасних інформаційних i комп'ютерних технологій, практично неможливо. Програмні інструментарії, безумовно, підвищують якість здійснення проєкту, в тому числі завдяки прискоренню введення та обробки інформації, поданню інформації в наочній формі. Керівнику проєкту необхідно контролювати проєкти у різних аспектах: зміст, розклад робіт, вартість, ресурси, комунікації, ризики, зацікавлені сторони. Зростаюча складність проєктів, у 3С України збільшує кількість зацікавлених сторін, що впливають на цілі проєкту та процес завершення проєктів, - задача аналізу вибору інтеграцій у програмних інструментаріїв ускладняється, підвищується рівень невизначеності на усіх стадіях проєкту, що потребує створення планів 3 управління проєктами використовуючи нові інтеграції 3 різними програмними засобами [5]. Для цього потрібні спеціальні знання, а також специфічні навички, які приходять iз досвідом. Завдання використання у 3С України інтеграцій програмних інструментаріїв ведення проєктів у відомчій нормативній базі залишається неврегульованим відповідно до рекомендацій ДСТУ, міжнародних стандартів і рекомендацій усталених світових практик управління проєктами i, відповідно, не має систематичної методичної підтримки[6-8]. Процес управління проєктом можна значно полегшити, якщо проєктна команда використовуватиме програмні інструментарії, які створені спеціально для цих цілей. Сучасні інформаційні системи, розроблені на замовлення Міністерства оборони України та Збройних Сил України, нині перебувають на різних стадіях життєвого циклу, що підтверджує зацікавленість у прискореній інтеграції існуючих програмних інструментаріїв ведення проєктів на різноманітних програмних платформах, i прийняття на озброєння. Ці чинники ускладнюють завдання досягнення інтеграції між автоматизованими системами, що вже прийняті на озброєння i які готуються для прийняття [7].

Аналіз останніх досліджень та публікацій. Проведений аналіз показав, що не існує ідеальних інструментаріїв ведення проєктів, оскільки всі проєкти різні та для кожного існують різні цілі та ресурси. У [1] розглядається управління розробленням Єдиної автоматизованою системою у 3С України. У [2] представлені моделі та інформаційні технології, які можуть бути використані для підтримки виконання проєктів на різних етапах виконання. Існує велика кількість програмного інструментарію, метою застосування якого $є$ підвищення ефективності реалізації проєкту (розуміється, насамперед, виконання як проєкту в цілому, так і його окремих етапів у задані терміни і в рамках затверджених асигнувань). У [3] проводиться аналіз зарубіжного та вітчизняного досвіду управління проєктами 3 впровадження інформаційних технологій та наданні обгрунтованих рекомендацій щодо реалізації ІТ-проєктів в автомобільному господарстві військових формувань. Також не існує програмних інструментаріїв, які б підходили кожному керівнику i були зручними для всіх членів команди. За час існування проєктного управління було 
створено чимало ефективних програмних інструментаріїв, які використовувались у різних галузях (архітектура будівництва, інформаційні технології, транспортній та інші). Такі інструментарії забезпечують зберігання, обробку та аналіз даних про хід здійснення проєкту, виконання аналітичних i прогнозних розрахунків, а також розрахунків, які забезпечують вибір під час прийняття рішень [4].

Метою статті $\epsilon$ аналіз підходів до вибору програмних інструментаріїв ведення проєктів для потреб Збройних Сил України.

Виклад основного матеріалу. Сучасні дослідження доводять, що командна робота буде ефективною за умови використання новітніх інформаційних технологій. Існуючі інформаційні технології представлені комплексом, який охоплює комп'ютерну мережу, Інтернет і засоби контролю. Інформаційні технології суттєво впливають на характер управлінської діяльності корпорацій, взаємовідносини у колективі, стосунки керівництва та виконавців, освоєння ринків і вибір стратегії. Комп'ютерні інформаційні технології значно впливають на те, як члени команди чи групи пов'язані між собою (сприяють груповій роботі). Виконання проєктних дій здійснюється із використанням інструментаріїв ведення проєктів. Найбільш широко представленими пакетами програмних інструментаріїв ведення проєктів для оптимізації діяльності корпорацій є такі: MS Project 2019, Wrike, Bitrix24, Oracle Primavera, та інші. Існуючі програмні інструментарії виконують майже однаковий набір функцій, інтерфейс їх також подібний. Однак існує низка відмінностей між цими програмними інструментаріями, що дає змогу фахівцеві вибрати продукт, найзручніший 3 його погляду.

MS Project 2019 вже став класичним інструментом, яким володіють майже всі керівники проєктів. 3 кожною новою версією MS Project стає все більш гнучким і зручним інструментом. MS Project 2019 отримав нові функції:

множинні призначення на завдання групи;

можливість приховувати діаграму Ганта і згортки;

управління деталізацією почасових

даних для звітів; 2019); підвищена продуктивність.

вимоги: не нижче Windows Server 2016, SQL Server 2017.

Примітка. Agile - гнучкий підхід до управління проєктами і продуктами, орієнтований на динамічне формування вимог і забезпечення їх реалізації внаслідок постійної взаємодії всередині самоорганізованих робочих груп, які складаються 3 фахівців різного профілю. Існує безліч методів, які базуються на ідеях Agile, найпопулярніші - Scrum i Kanban. Agile - це скоріше набір ідей і принципів того, як потрібно реалізовувати проєкти. [3].

MS Project 2019 постачається у двох варіантах: у хмарі - як сервіс, і як ліцензійне ПЗ для установки на комп'ютерах. Для хмарних рішень $є$ мобільні додатки MS Project 2019 для iOS та Android. До переваг системи MS Project 2019 можна віднести швидкий i продуманий інтерфейс, можливість використання як для Waterfall, так і для Agile проєктів, можливість організації віртуальних робочих команд, використання Skype for Business, відмінна сумісність 3 MS Office, розвинені засоби для аналізу портфеля проєктів, можливість застосування в дуже великих компаніях із сотнями або й тисячами проєктів. До мінусів - порівняно висока вартість підписки, висока вартість рішень, які постачаються. Корпорація ABANCA, за допомогою Microsoft project поліпшила управління проєктами, щоб гнучко реагувати на зміну ринкових тенденцій. На той момент компанія вже використала Microsoft Project Server. Впровадження Project Online дозволило остаточно централізувати управління корпоративним портфелем проєктів i полегшити роботу зі звітами. Корпорація Enterprise Commerce за допомогою розширень для Microsoft Visual Studio Team Foundation Server підрозділ ЕC інтегрувала Microsoft Project Online i TFS i сформувала єдиний репозиторій завдань i структуру відстеження. Компанія Saudi Aviation Information Technology використовує Microsoft Project Online i Power BI для прийняття поінформованих рішень щодо оцінювання ефективності роботи компанії. Компанія Scania перевела всі свої європейські підрозділи на Microsoft Project Online. Нові рішення для управління проєктами та портфелями розширило можливості провідних інженерів і дало змогу в три рази збільшити число успішно виконаних проєктів [3].

Основні інтеграції MS Project 2019 з іншими програмними сервісами:

microsoft power BI - сервіс спростив отримання інформації 3 різних середовищ $\mathrm{i}$ керування даними будь-якого обсягу i 
структури за допомогою знайомих інструментів Office 365 ;

docSpace - система управління електронними документами i робочими процесами на платформі MS SharePoint 2013 відноситься до класу систем ЕСМ (Управління корпоративних інформаційних контентом або Системи електронного документообігу);

saperion elm - рішення 3 управління життєвим циклом електронної пошти, забезпечуючи інтеграцію обороту електронної пошти в масштабах усього підприємства.

rike.com - це хмарний сервіс, який надає проєктній команді зручні інструменти для управління проєктами. У робочій області можна вести список завдань, відстежувати статус завдань із допомогою канбан-дошки, давати завдання виконавцям, визначати контрольні терміни виконання завдань. Wrike дає змогу створювати проєкти за такими шаблонами:

проєкт із залежними завданнями;

складний багатоетапний проєкт;

вхідні запити 3 твердженням;

професійні послуги;

проєкт канбан;

управління заходом.

Wrike дає змогу налаштувати форми збору даних, що впорядковує процес збору вимог до продукту. Wrike має додатки для Windows, Mac, iOS, Android, а також безліч плагінів для популярних програм: wrike для Outlook, wrike для документів Office, wrike для Gmail, двостороння синхронізація wrike i jira, редактор документів wrike та iнші. Система Wrike має засоби моніторингу ходу виконання проєктів. Керівник проєкту може сформувати: звіт про виконання завдань; фактичні витрати; про активні та прострочені завдання; звіт про завдання, які не мають виконавців та інші аналітичні звіти про роботу. До переваг системи Wrike можна віднести можливість організації віртуальних робочих команд. До мінусів - відсутність IPтелефонії і відсутність коштів проведення презентацій i вебінарів. Корпорація TGI Fridays підвищила за допомогою Wrike кількість i якість виконання стратегічних проєктів завдяки злагодженій роботі різних відділів [4]. 3'явилась можливість відслідковувати деталі кожного завдання, щоб знати, що все буде готово до моменту запуску, та контролювати хід проєкту, і це призвело до зниження витрат корпорації. Компанія Airbnb, використовуючи БД Wrike, підвищила якість матеріалів, їх узгодження та моніторингу ефективності роботи проєкту. Спільно 3 Microsoft Wrike розробили інструмент, який дає змогу користуватися потужними функціями і можливостями чату Teams. Тепер користувачі Теams можуть створювати завдання і управляти проєктами, підтримуючи робоче спілкування і співпрацюючи, в Office $365[4]$.

Основні інтеграції Wrike 3 іншими програмними сервісами:

Sallesforce (система управління відносинами 3 клієнтами) - дає змогу команді продажів отримати чітке уявлення про хід робіт за проєктами клієнтів;

ProofHQ (системи управління контентом) - прискорює процеси узгодження документів у команді;

Dropbox (зберігання файлів) - об'єднує сховище файлів і завдання;

Інтеграція 3 електронною поштою можливість створення та делегування i редагування завдання у поштовому клієнту;

Jira - синхронізація завдань і проєктів для успішної співпраці між відділами і більш ефективної роботи над декількома проєктами.

Bitrix24 надає не тільки функціонал для управління проєктами, а й функції для ведення бізнесу. До переваг системи Bitrix 24 можна віднести: швидкий i продуманий інтерфейс, схожий на соціальні мережі; можливість організації віртуальних робочих команд; вбудовану IP-телефонію; можливість проведення віддалених демонстрацій та вебінарів; можливість управління процесами не тільки проєктів, але і системи управління відносинами 3 клієнтами, бізнес процесів організації, сайтів і магазинів. Bitrix24 можна використовувати як у класичних Waterfall проєктах, так і в проєктах Agile. До недоліків можна віднести тільки дещо незвичний оригінальний інтерфейс. Мережа “Ощадбанк” за допомогою Bitrix24 (новий офіційний сайт) став зручним інструментом для обслуговування та задоволення всіх фінансових потреб різних типів клієнтів - від роздрібних до корпоративних. Уся мережа банку УкрСіббанк переведена на платформу "1C-Бітрікс". Новий сайт компанії має високий рівень безпеки, забезпечує швидкий доступ до найактуальнішої інформації 3 фінансових пропозицій i можливостей, здатний витримувати високі навантаження i оснащений інтерактивною картою відділень [4].

Основні інтеграції Bitrix24 3 іншими програмними сервісами: 
Google Analytics - сервіс від компанії Google, що дає змогу проаналізувати дії відвідувачів вашого сайту. Здійснюється аналіз соціальної активності сторінок сайту, надається абсолютно безкоштовно;

P1SMS - здійснює автоматизацію масових розсилок SMS-повідомлень, розсилки в Telegram, Viber, WhatsApp, автообзвон абонентів, а також можливість налаштувати таргетовану рекламну кампанію. Доступні і каскадні розсилки, які задіють відразу кілька каналів для відправки повідомлень;

Worksection спеціалізується на управління проєктами, надаючи клієнтам широкий набір інструментів для планування i організації проєктів, управління комунікаціями в його рамках і отримання детальних звітів;

MySQL - дає змогу інтегрувати систему управління базами даних із сервісами $\mathrm{i}$ системами, які використовуються для свого бізнесу;

onlinePBX - це віртуальна АTC, яка може бути інтегрована 3 власної CRMсистемою більшості бізнес-проєктів;

Oracle Primavera $-\epsilon$ платним інструментарієм управління проєктами, програмами i портфелями проєктів, розроблений корпорацією Oracle i призначений для керівників проєктів для допомогти їм у розробленні календарних планів, розподіленні ресурсів і фінансів за завданнями, контролю ходу виконання проєкту і аналізі обсягів робіт. Продукт Oracle Primavera орієнтований на такі області діяльності: будівництво та інженерні роботи, аерокосмічний сектор і оборона, видобуток нафти i газу, машинобудування, комунальні підприємства, професійні послуги. Плюси Oracle Primavera: професійна система, призначена для великих компаній і великого бізнесу; інтеграція 3 електронним документообігом на базі SAP; стабільна i високопродуктивна робота системи; витримує величезні навантаження. Мінуси Oracle Primavera: продукт відноситься до високої цінової категорії рішення - можуть собі дозволити середній і великий бізнес; невелика популярність системи [4].

Основні інтеграції Bitrix 3 іншими програмними сервісами:

SAP Plant Maintenance - спрощуе впровадження і конфігурацію інтеграційних процесів на підприємствах;

SAP Project System - дає змогу отримувати цілісне уявлення про найважливіші проєктні дані на основі взаємодій з ERP-системами, а також імпорту та експорту даних з Oracle Primavera EPPM;

eTimeMachine створює зручний для користувача i ефективний простір для управління проєктами, розробляючи призначений для користувача інтерфейс залежно від ролі користувача в проєкті;

1C: ERP + PM демонструє можливість зв'язку управління проєктною організацією 3 використанням механізму вебсервісів 3 боку Primavera.

Основні порівняльні характеристики розглянутих програмних інструментаріїв наведені у табл. 1

Таблиця 1

\begin{tabular}{|c|c|c|c|}
\hline $\begin{array}{c}\text { Назва } \\
\text { інструментарію }\end{array}$ & Керування завданнями & $\begin{array}{c}\text { Основні інтеграції з іншими } \\
\text { сервісами }\end{array}$ & Розгортання \\
\hline MS Project & $\begin{array}{l}\text { Керування роботою, керування } \\
\text { потребами, керування часом і } \\
\text { завданнями, керування ресурсами, } \\
\text { керування планами, керування } \\
\text { програмами }\end{array}$ & $\begin{array}{l}\text { Jira, MS Planer, Redmine, } \\
\text { Elma, DocSpace,1C, Oracle, } \\
\text { SAP R/3, Scala, MS Excel, MS } \\
\text { SharePoint, Wrike,Axapta, } \\
\text { SWE-PDM, 3SL Cradle, } \\
\text { saperion elm, Microsoft Power } \\
\text { BI }\end{array}$ & $\begin{array}{l}\text { хмара, } \\
\text { сервер }\end{array}$ \\
\hline Wrike & $\begin{array}{l}\text { Управління завантаженням команди, } \\
\text { облік часу і бюджетування, } \\
\text { комунікації, персональна панель задач, } \\
\text { узгодення, стрічка новин у } \\
\text { реальному часі, мобільні пристрої, } \\
\text { синхронізація електронної пошти та } \\
\text { календарів }\end{array}$ & $\begin{array}{l}\text { Salesforce, Box, Google disk, } \\
\text { Microsoft OneDrive, Jira, } \\
\text { Github, Saml, Okta, MS Project, } \\
\text { MS Excel, Office Timeline, } \\
\text { Bitium, Dpopbox, Android App, } \\
\text { Linkedln, Marketo, ProofHQ, } \\
\text { OneLogin, PingFederate }\end{array}$ & хмара \\
\hline Bitrex24 & $\begin{array}{l}\text { Картка CRM та спілкування, } \\
\text { автоматизація продажів, CRM } \\
\text { маркетинг, дзвінки з CRM, листи } 3\end{array}$ & $\begin{array}{l}\text { Chatfuel,LP-CRM, PrestaShop, } \\
\text { Smart Sender, Chatra, LPMotor, } \\
\text { PrivatBank (фіз. Особи), }\end{array}$ & $\begin{array}{l}\text { хмара, } \\
\text { сервер }\end{array}$ \\
\hline
\end{tabular}




\begin{tabular}{|c|c|c|c|}
\hline $\begin{array}{c}\text { Назва } \\
\text { інструментарію }\end{array}$ & Керування завданнями & $\begin{array}{c}\text { Основні інтеграції з іншими } \\
\text { сервісами }\end{array}$ & Розгортання \\
\hline & $\begin{array}{l}\text { CRM, безкоштовний онлайн чат, план } \\
\text { продажів і звітів, генератор продажів, } \\
\text { документи у CRM, CRM для послуг, } \\
\text { обмін даними з BAS, бек-офіс 1c, } \\
\text { сайти CRM, CRM аналітика, наскрізна } \\
\text { аналітика }\end{array}$ & $\begin{array}{l}\text { SmartCallBack, МойСклад } \\
\text { Contact Form 7, LPgenerator, } \\
\text { Prom, Smartloop, Нова Пошта, } \\
\text { Creatio, Landingi, ProstoSMS } \\
\text { SnatchBot, Нью-Tел, DC Lite, } \\
\text { LeadBack,PushSMS, Stream } \\
\text { Telecom, DashaMail, } \\
\text { LeadForms Puzzlebot, Talk-me, } \\
\text { PeмOнлайн E-Autopay, Leeloo, } \\
\text { Pyrus, Tap2pay, CMC } \\
\text { Дисконт, Ecwid LiveChat, } \\
\text { QuizGO, Taplink, Tелеграм, } \\
\text { Enquiz, Livetex, Ramex CRM, } \\
\text { TargetSMS, Envybox, MCN } \\
\text { Telecom, RedSMS, TextBack, } \\
\text { Estismail Mailchimp, Reply.io, } \\
\text { TildaEvecalls, MailerLite, } \\
\text { Retail CRM Timepad, } \\
\text { ExpertSender, Mailganer, } \\
\text { Ringostat, TopVisor }\end{array}$ & \\
\hline $\begin{array}{c}\text { Oracle } \\
\text { Primavera P6 }\end{array}$ & $\begin{array}{l}\text { Планування, контроль виконання } \\
\text { проєктів, керування пріоритетами } \\
\text { проєктів портфеля компанії і вибір } \\
\text { інвестиції в проєкти, розподілення } \\
\text { ресурсів, забезпечення виконання } \\
\text { термінів, скорочення витрат }\end{array}$ & $\begin{array}{l}\text { SAP Plant Maintenance, SAP } \\
\text { Project System, eTimeMachine, } \\
\text { 1C: ERP + PM, CAD Lib, } \\
\text { Lotsia PDM PLUS. }\end{array}$ & $\begin{array}{l}\text { хмара, } \\
\text { сервер }\end{array}$ \\
\hline
\end{tabular}

Висновок. Таким чином у сучасних умовах розвитку програмні інструментарії управління проєктами дають змогу автоматизувати всі основні операції 3 управління підприємствами на різних стадіях впровадження проєктів у різні галузі. Розглянуті у статті інтеграції до інструментальних продуктів дають змогу дійти висновку щодо динамічного розвитку напряму управління проєктами у різних сферах підприємницької діяльності. Упровадження інструментаріїв управління проєктами у Збройних силах України дасть змогу отримати таки переваги:

оптимізацію розроблення розкладу виконання робіт проєкту без урахування і 3 урахуванням обмеженості ресурсів; визначення потреби проєкту у фінансуванні та ресурсному забезпеченні; оцінювання ризиків і планування проєкту з їх урахуванням; часі; аналіз виконання проєкту у реальному

визначення відхилень виконання робіт від запланованого і прогнозування основних параметрів проєкту.

Аналізуючи можливі інтеграції розглянутих інструментаріїв та швидкий $\mathrm{i}$ продуманий інтерфейс, можливість організації віртуальних робочих команд, використання відеоконференцій, відмінна сумісність 3 MS
Office 365 , розвинені засоби для аналізу портфеля проєктів, та досвід застосувань інструментарію у дуже великих компаніях доцільне використання Microsoft Project для ведення проєктів військового призначення.

\section{СПИСОК ВИКОРИСТАНОЇ ЛІТЕРАТУРИ}

1. Морозов А. О., Косс В. А. Управління розробкою Єдиної АСУ збройних сил. Наука $\mathrm{i}$ оборона. 2006. № 2. C. 30-34. URL: http://www.immsp.kiev.ua/perspages/

koss_va/publ/5_syst_proekt.pdf.

2. Войтенко О. С. Когнітивні моделі та інформаційні технології управління проєктами та програмами : автореф. дис. ... канд. техн. наук : 05.13.22. Київ, 2008. 22 с.

3. Ноздріна Л. В., Ящук В. І., Полотай О. I. Управління проєктами : підручник. Київ: Центр навчальної літератури, 2018. 432 с.

4. Аналіз зарубіжного та вітчизняного досвіду управління проєктами 3 впровадження інформаційних технологій / А. А. Рибидайло та ін. // Збірник наукових праць Центру воєнностратегічних досліджень Національного університету оборони України імені Івана Черняховського. Київ, 2015. № 1 (53). С. 55-64.

5. Инюшкина О. Г. Проектирование информационных систем (на примере методов структурного системного анализа) : учеб. пособие. Екатеринбург : Форт-Диалог Исеть, 2014. $240 \mathrm{c}$.

6. ДСТУ ISO/IEC/IEEE 15288:2016. Інженерія систем і програмного забезпечення. Процеси 
життєвого циклу систем. (ISO/IEC/IEEE 15288:2015, IDT). [Чинний від 2016-12-27]. Вид. офіц. Київ : УкрНДНЦ, 2018. 84 с.

7. ДСТУ ISO/IEC 15289:2014. Інженерія систем i програмного забезпечення. Контент життєвого циклу інформаційної продукції (документації): (ISO/IEC 15289:2011). [Чинний від 2014-12-30].

8. ДСТУ ISO/IEC 16085:2016. Інженерія систем і програмних засобів. Процеси життєвого циклу.
Керування ризиками: (ISO/IEC 16085:2006, IDT). [Чинний від 2016-12-27]. Вид. офіц. Київ : УкрНДНЦ, 2018. 34 с.

9. ДСТУ ISO/IEC/IEEE 16326:2015. Розроблення систем та програмного забезпечення. Процеси життєвого циклу. Керування проєктами: (ISO/IEC/IEEE 16326:2009, IDT). [Чинний від 2015-12-18]. Вид. офіц. Київ : УкрНДНЦ, 2015. $31 \mathrm{c}$.

Стаття надійшла до редакційної колегії 30.07.2020

\section{Analysis of integrations of software tools for project management and their use for the needs of the Armed Forces of Ukraine.}

\section{Annotation}

It is almost impossible to ensure effective project management in various spheres of activity of the Armed Forces of Ukraine without the usage of modern information and computer technologies. The project management process can be greatly facilitated if the project team uses software tools created for this purpose. Some modern information systems, commissioned by the Ministry of Defense and the Armed Forces of Ukraine, are still at different stages of the life cycle. This course of events confirms the interest in the accelerated integration of existing software tools for project management on various software platforms and their subsequent adoption.

The aim of the article is to analyze the approaches to the selection of software tools for project management for the needs of the Armed Forces of Ukraine.

The most widely represented packages of software tools for project management to optimize the activities of corporations are MS Project 2019, Wrike, Bitrix24, Oracle Primavera, and others. They perform almost the same set of functions, however, there are a number of differences between these tools, which allows the specialist to choose the most convenient product for him.

he article is devoted to the analysis of problems of assessment of the suitability of tools of conducting projects of various scales in the process of the creation of information systems of military purpose. Examples of already implemented projects are given, the advantages and disadvantages of some basic software tools are identified and described.

After analyzing the existing tools, it is proposed to use the Microsoft Project special software for projects in the military sphere. The analysis took into consideration the usability of the interface, the organization of virtual work commands, the use of video conferencing, compatibility with MS Office 365 , and other useful features.

Keywords: project management; project management tools; resource management. 